\title{
COMPLETE BOUGUER GRAVITY MAP OF THE NEVADA TEST SITE AND VICINITY, NEVADA
}

\section{By}

D. L. Healey, R. N. Harris D. A. Ponce and H. W. Oliver

1987

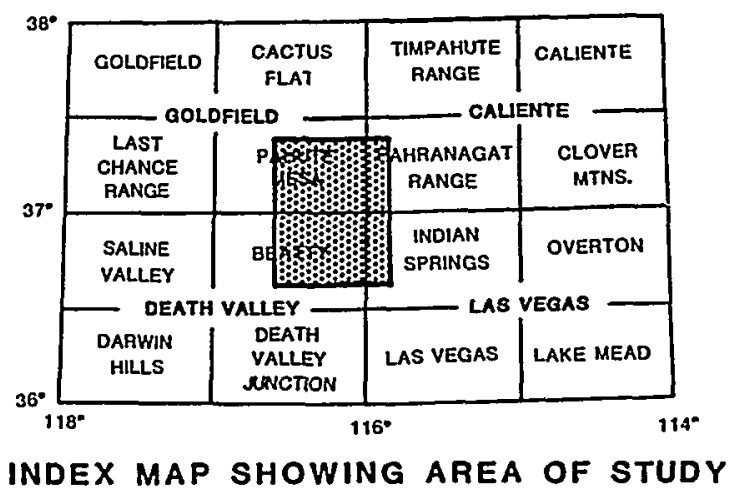

\section{Open-File Report 87-506}

Prepared in cooperation with the

Nevada Operations Office

U.S. Department of Energy

(Interagency Agreement DE-AIO8-78ET44802)

This report is preliminary and has not been reviewed for conformity with U.S. Geological Survey editorial standards and stratigraphic nomenclature. Any use of trade names is for descriptive purposes only and does not imply endorsement by the U.S. Geological Survey.

Menlo Park, California 1987 


\section{DISCLAIMER}

This report was prepared as an account of work sponsored by an agency of the United States Government. Neither the United States Government nor any agency thereof, nor any of their employees, make any warranty, express or implied, or assumes any legal liability or responsibility for the accuracy, completeness, or usefulness of any information, apparatus, product, or process disclosed, or represents that its use would not infringe privately owned rights. Reference herein to any specific commercial product, process, or service by trade name, trademark, manufacturer, or otherwise does not necessarily constitute or imply its endorsement, recommendation, or favoring by the United States Government or any agency thereof. The views and opinions of authors expressed herein do not necessarily state or reflect those of the United States Government or any agency thereof. 


\section{DISCLAIMER}

Portions of this document may be illegible in electronic image products. Images are produced from the best available original document. 


\section{VATION}

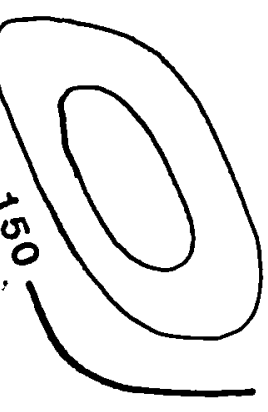

\section{IALY CONTOURS}

1. Hachures indicate gravity low. ed based on a 250-meter grid interata. Although the data have been ised when interpreting anomalies point.

\section{STATION}

SE STATION

\section{GRAVITY STATION}

\section{AVITY STATION}

POTENTIAL HIGH-LEVEL T YUCCA MOUNTAIN inergy, 1984, p. 3-18)
USGS-OFR--87-506

TI89 007464

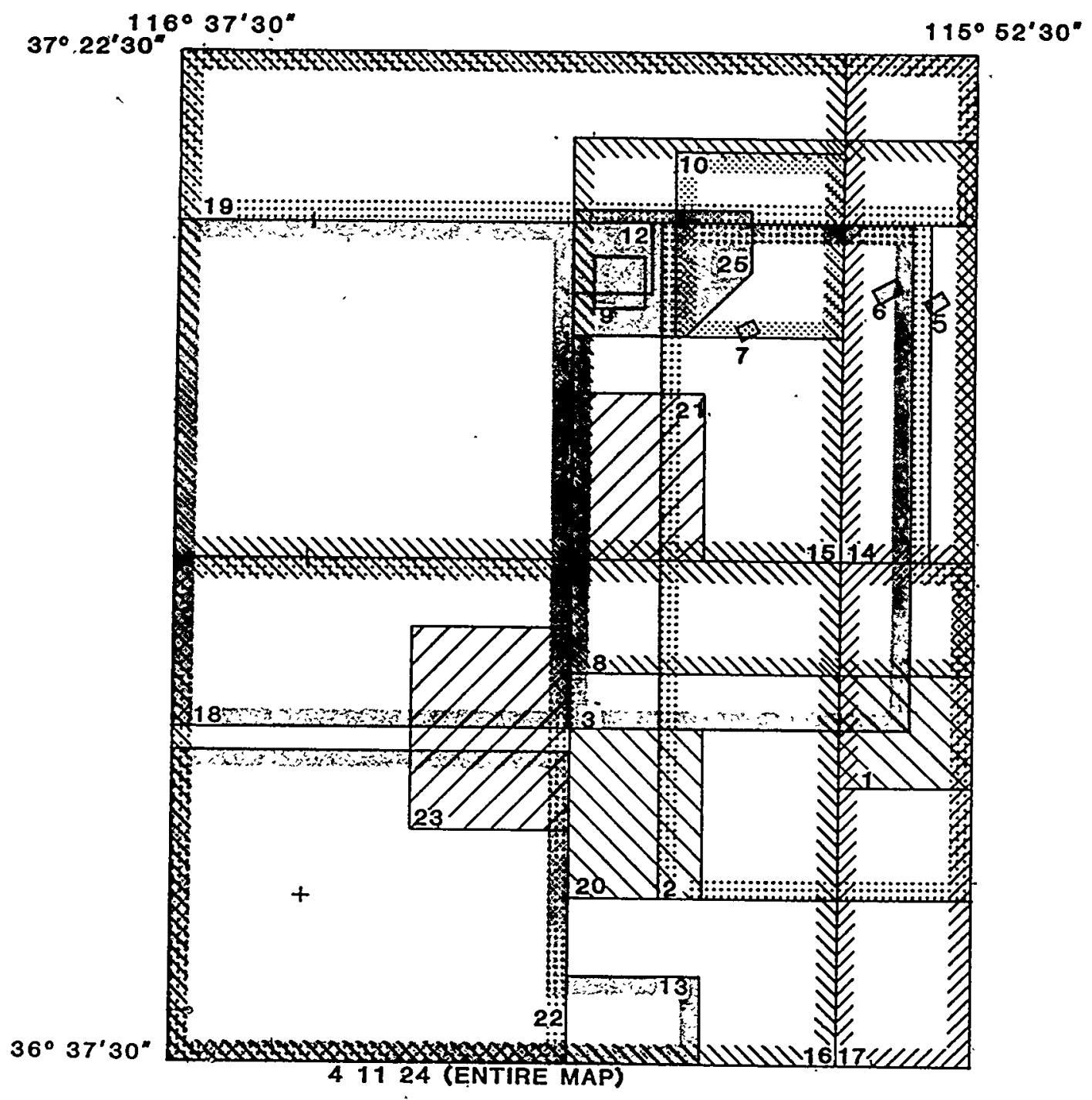

Figure. 1.-Index of NTS gravity maps (see table 1). 


\section{(19) (1)}

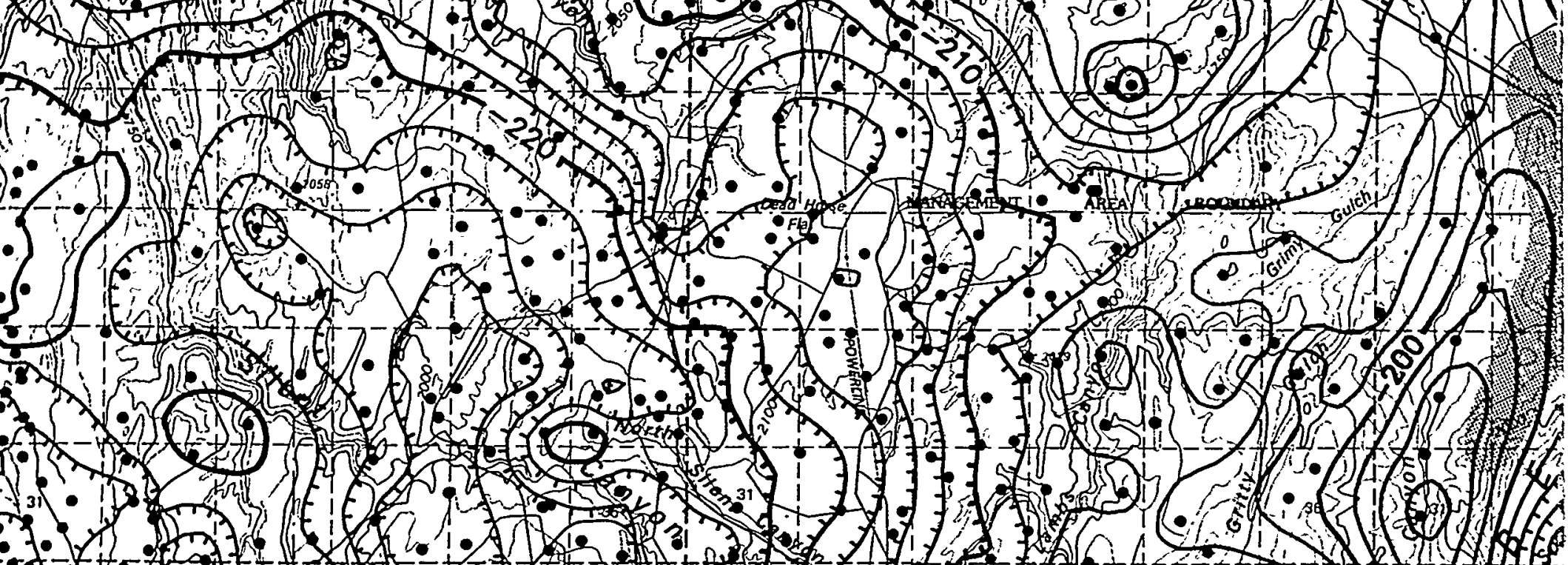

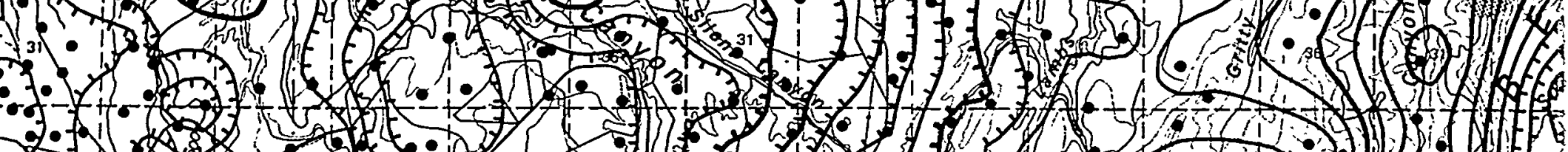
65

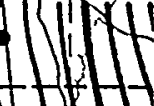
(15) - of 然

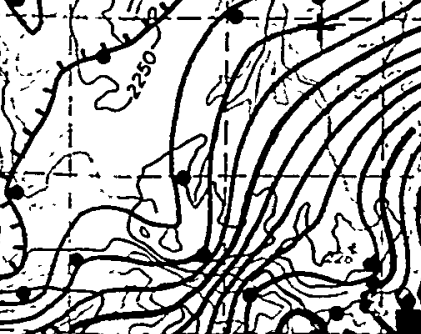

(3). 10 -

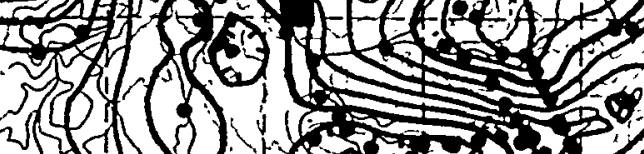
5) 103 i. 35 . 35 H If 1 (s) (16) 

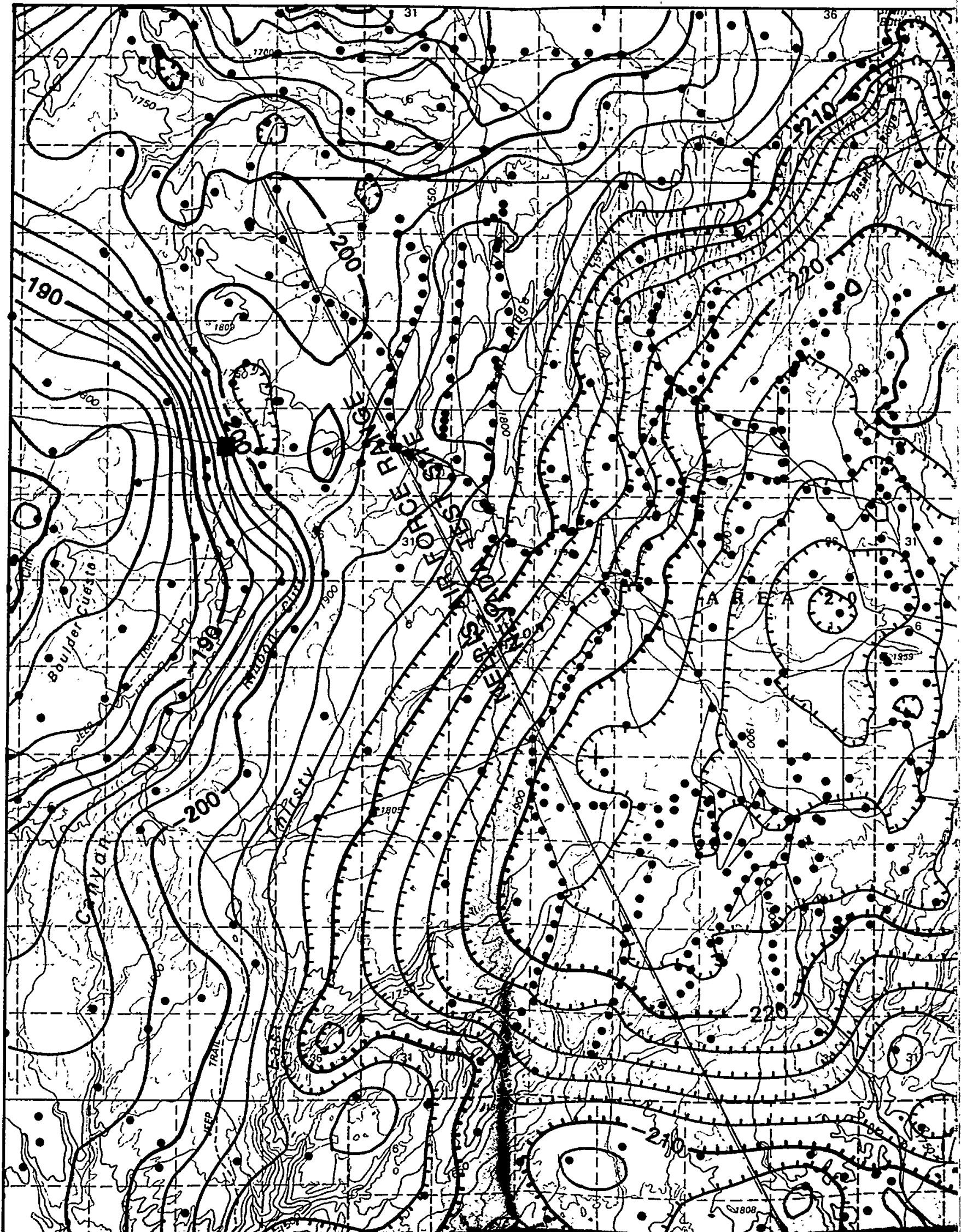


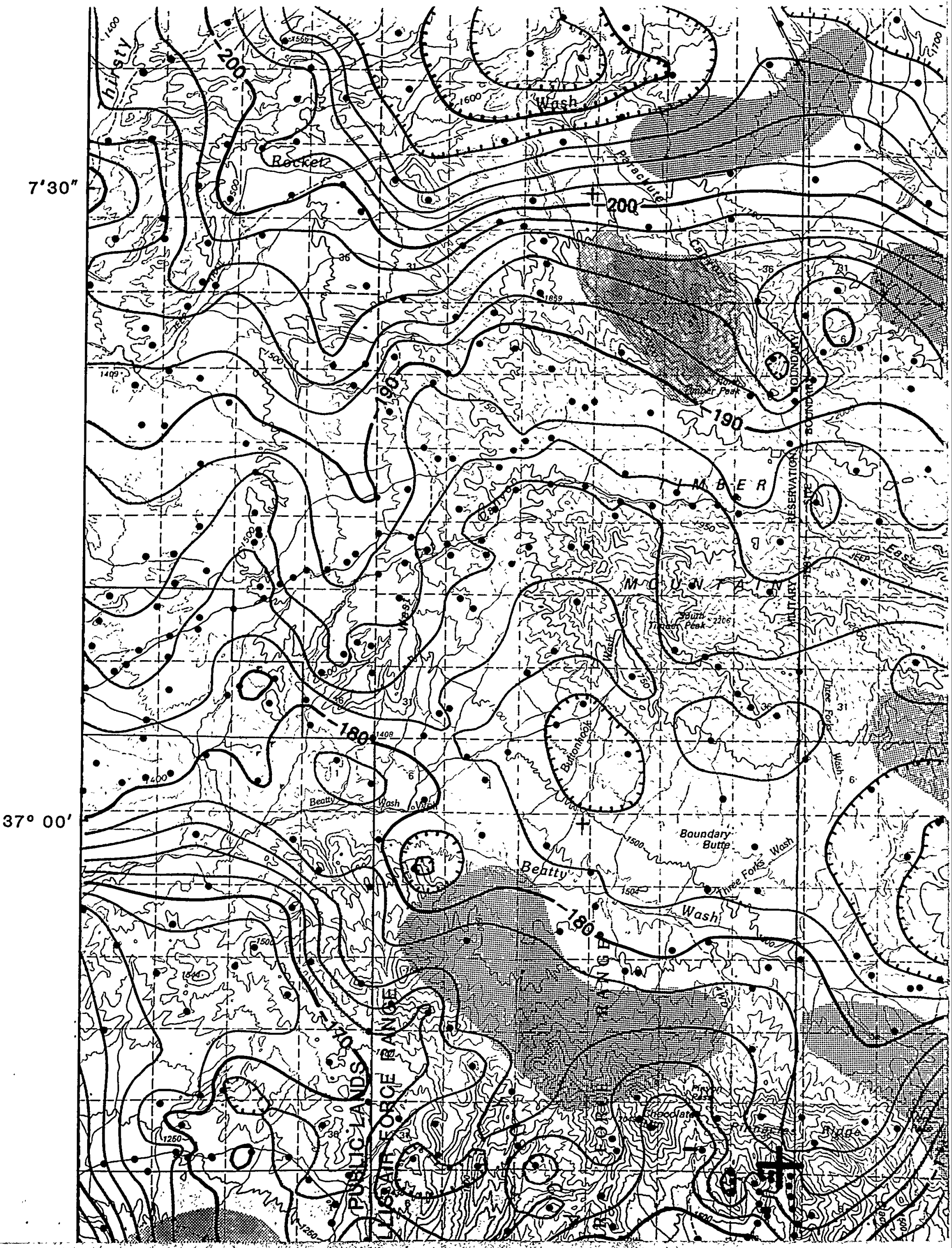




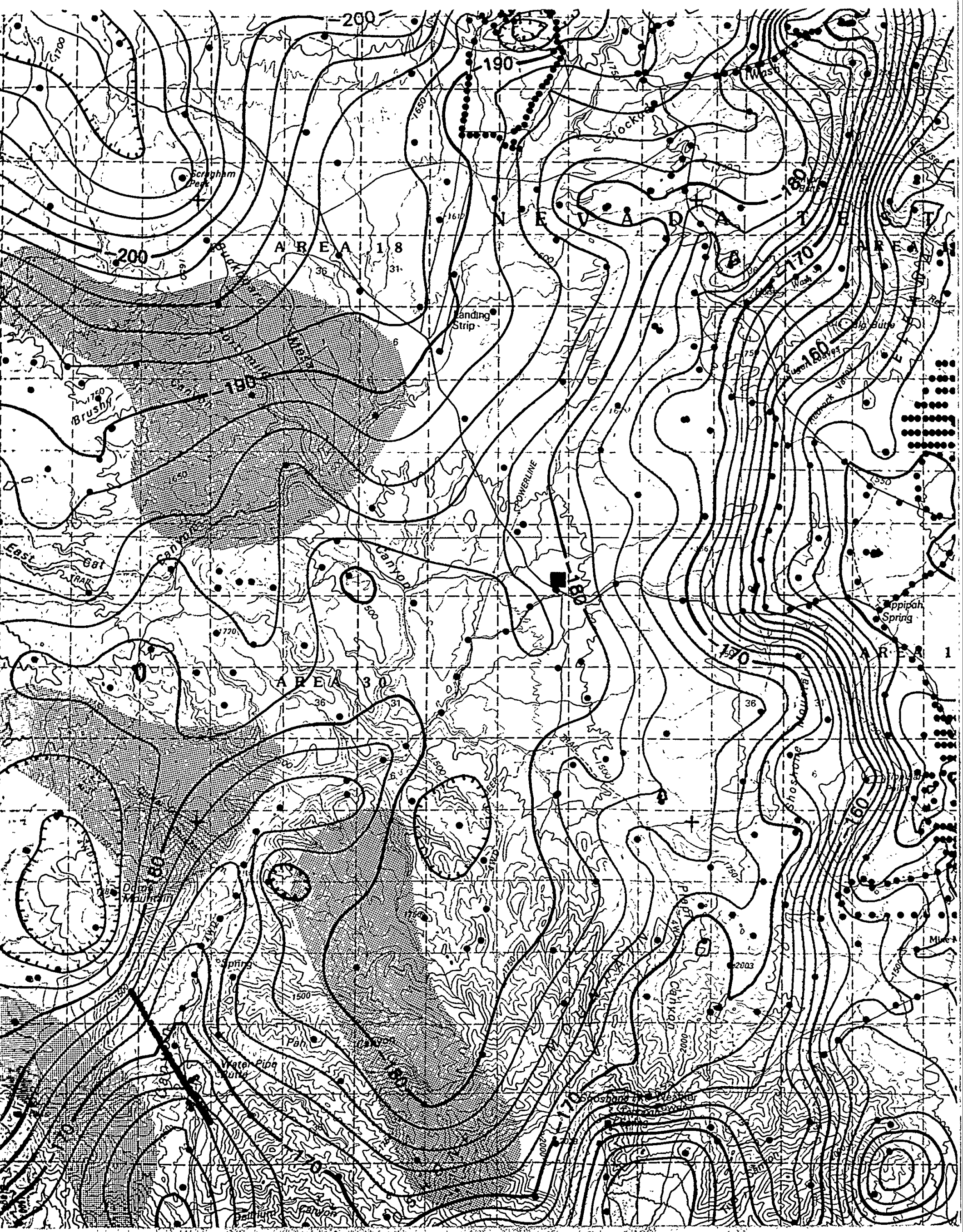




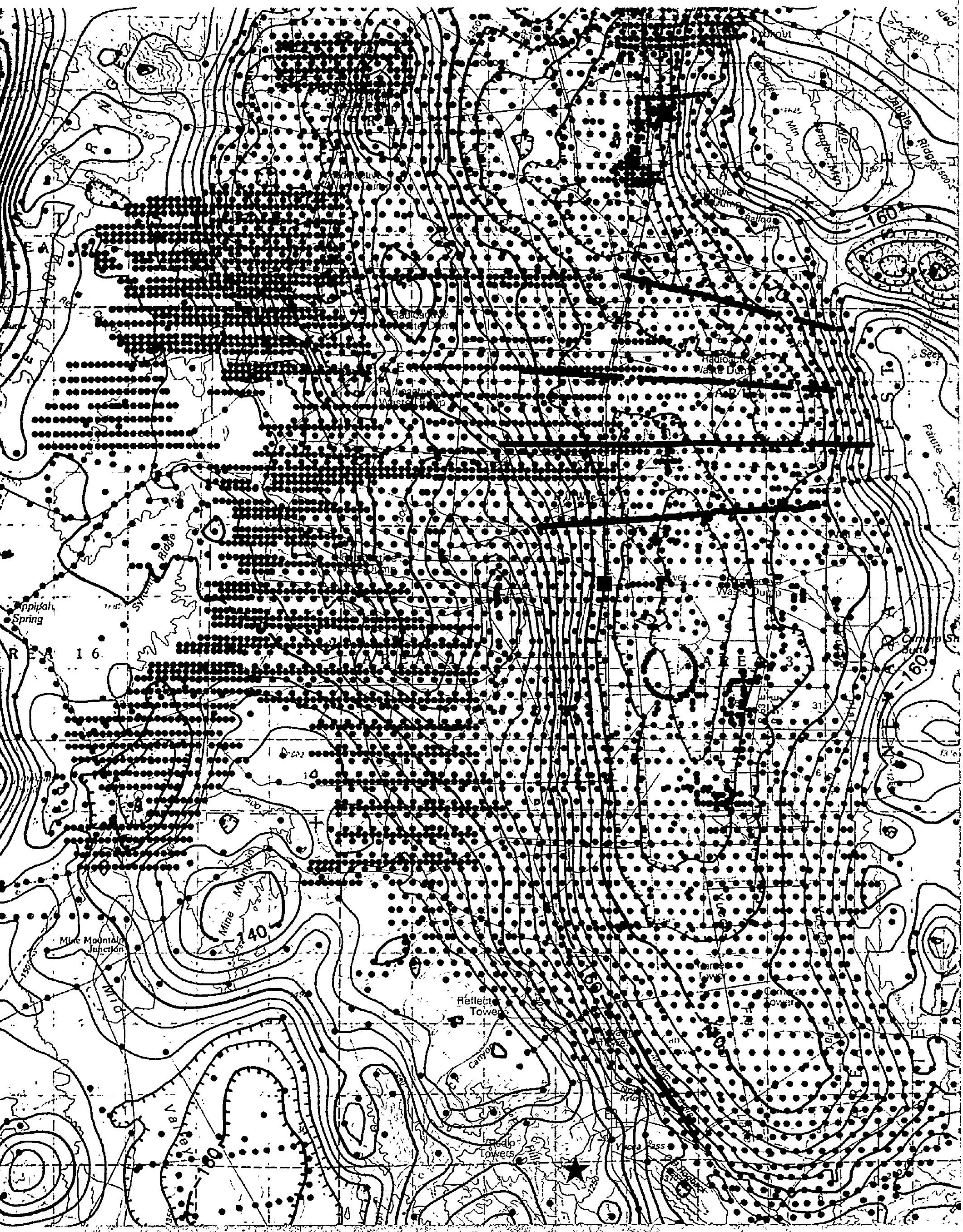


AREAS OF POORIGRAVITY STI Areas where the station density is genera 2 by $2 \mathrm{~km}$ and 2 stations, per 3 by $3 \mathrm{kr}$ additional control may be needed in ares or geologically complex.

\section{DISCUSSIOE}

This map is based on about 15,000 between 1956 and 1986 in conjunction wi Nevada Test Site (NTS). Principal facts described by Harris and others (1989) scriptions of gravity base stations, the n? complete Bouguer anomaly values, and a ters used and their calibration factors. are referenced to the International Grat 1971 gravity datum described by Morell anomalies were calculated by using the this the Geodetic Reference System 1967 forn ity on the ellipsoid (International Associn $60)$ and Swick's formula (1942, p. 60) fe Bouguer, curvature, and terrain correctic tion density of $2.67 \mathrm{~g} / \mathrm{cm}^{3}$ were added te determine complete Bouguer anomalies. made to a radial distance of $166.7 \mathrm{~km}$ fron ital elevation model and a computer proces include manually estimated inner-zone available.

Gravity studies at the NTS were und ologically favorable areas for undergrounci geologically characterize potential high-le sites. Figure 1 is an index of NTS gravity for these maps are listed in table 1. Table mary of interpretive gravity reports at the? obtained during the 1960's in Yucca and define the depth and configuration of th Canyon caldera, approximately outlined in the northwest corner of the NTS was Mesa in the late 1960's based on gravity st tailed gravity data near Syncline Ridge, and Yucca Mountain in the southwest q: collected to help assess these areas as pcs waste storage sites (Ponce and Hanna, 1981; Ponce, 1981; Snyder and Carr, 198

Anderson, R. E., Ekren, E. B., and Her ble buried mineralized areas in Nye of Nevada, in Geological Surve Resears Survey Profescional Paper 525-D, p.

Carr, W. I, Bath, G. D., Heales, D. L.s 1975, Geology of northern Frenchmar U.S. Geologiçal Surrey Report USGG

Diment W H Healey, D. L., and Roll and seismere exploration in fucca $\mathrm{Ve}$ 


\begin{tabular}{ll}
\hline 1. Carr and others, 1975 & 14. Healey and others, 1981a \\
2. Diment and others, 1960 & 15. Healey and others, 1981b \\
3. Healey, 1966 & 16. Healey and others, 1980 \\
4. Healey, 1968 & 17. Kane and others, 1979; \\
5. Healey, 1969 & Reidy and others, 1979 \\
6. Healey, 1970a & 18. Kane and others, 1981 \\
7. Healey, 1970b & 19. Miller and others, 1974 \\
8. Healey, 1976a & 20. Ponce, 1981 \\
9. Healey, 1979 & 21. Ponce and Hanna, 1982 \\
10. Healey, 1983 & 22. Snyder and Carr, 1982 \\
11. Healey and Miller, 1962 & 23. Snyder and Oliver, 1981 \\
12. Healey and Miller, 1963 & 24. U.S. Geological Survey, 1968 \\
13. Healey and Miller, 1971 & 25. Wahl, 1969 \\
\hline
\end{tabular}

ont 15,000 gravity stations collected iunction with geologic studies at the acipal facts of the gravity data are rs (1989) and includes detailed deions, the methods used to compute lues, and a discussion of gravity men factors. Observed gravity values tional Gravity Standardization Net by Morelli (1974). Nree-air gravity sing the theoretical gravity based on 11 1967 formula for the normal gravnal Association of Geodesy, 1971, p. 2, p. 60) for the free-air correction. in corrections for a standard reducre added to the free air anomaly to anomalies. Terrain corrections were $6.7 \mathrm{~km}$ from each station using a digputer procedure by Plouff (1977) and nner-zone terrain correctious where

'S were undertaken to help locate genderground nuclear tests and to help tial high-level nuclear waste storage NTS gravity maps and the references ble 1 . Table 2 is a geographical sumports at the NTS. Detailed data were Yucca and Frenchman Flats to help ration of the basement. The Silent y outlined by the $-210 \mathrm{mGal}$ contonr - NTS was discovered under Paliute in gravity studies (Healey, 1968). Deline Ridge, Calico Hills, Wahmonie, outhwest quadrant of the NTS were areas as potential high-level nuclear id Hanna, 1982; Snyder and Oliver, d Carr, 1982)

\section{REFERENCES}

TABLE 2.-Interpretative gravity reports of the Nevada Test Site and vicinity

\begin{tabular}{ll}
\hline Geographic location & \multicolumn{1}{c}{ Reference } \\
\hline Calico Hills & Snyder and Oliver, 1981 \\
Caliente $1^{\circ} \times 2^{\circ}$ sheet & Snyder; 1983 \\
Climax Stock & Healey, 1983 \\
Frenchman Flat & Miller and Healey, 1986 \\
Pahute Mesa & Healey, 1968 \\
& Evans and Oliver, 1987 \\
Southern Nevada-Regional & Anderson and others, 1965 \\
& Diment and others, 1959 \\
Southwestern Nevada Test Site & Snyder and Carr, 1984 \\
Syncline Ridge & Ponce and Hanna, 1982 \\
Timber Mountain & Healey and Miller, 1979 \\
& Kane and others, 1981 \\
Yucca Flat & Healey, 1968; 1969 \\
North End & Healey, 1970a; 1970b; 1976a \\
Yucca Mountain & Healey and others, 1984 \\
Yucca Mountain and Vicinity & Snyder and Carr, 1982 \\
Wahmonie & Ponce, 1981; 1984 \\
\hline
\end{tabular}

B., and Healey, D. L., 1965, Possias in Nye and Esmeralda Counties, :ve Research 1965: U.S. Geological 525-D, p. D144-D150.

:aley, D. L., and Hazlewood, R. M., Frenchman Flat, Nevada Test Site: eport USGS-474-216,23 p. 


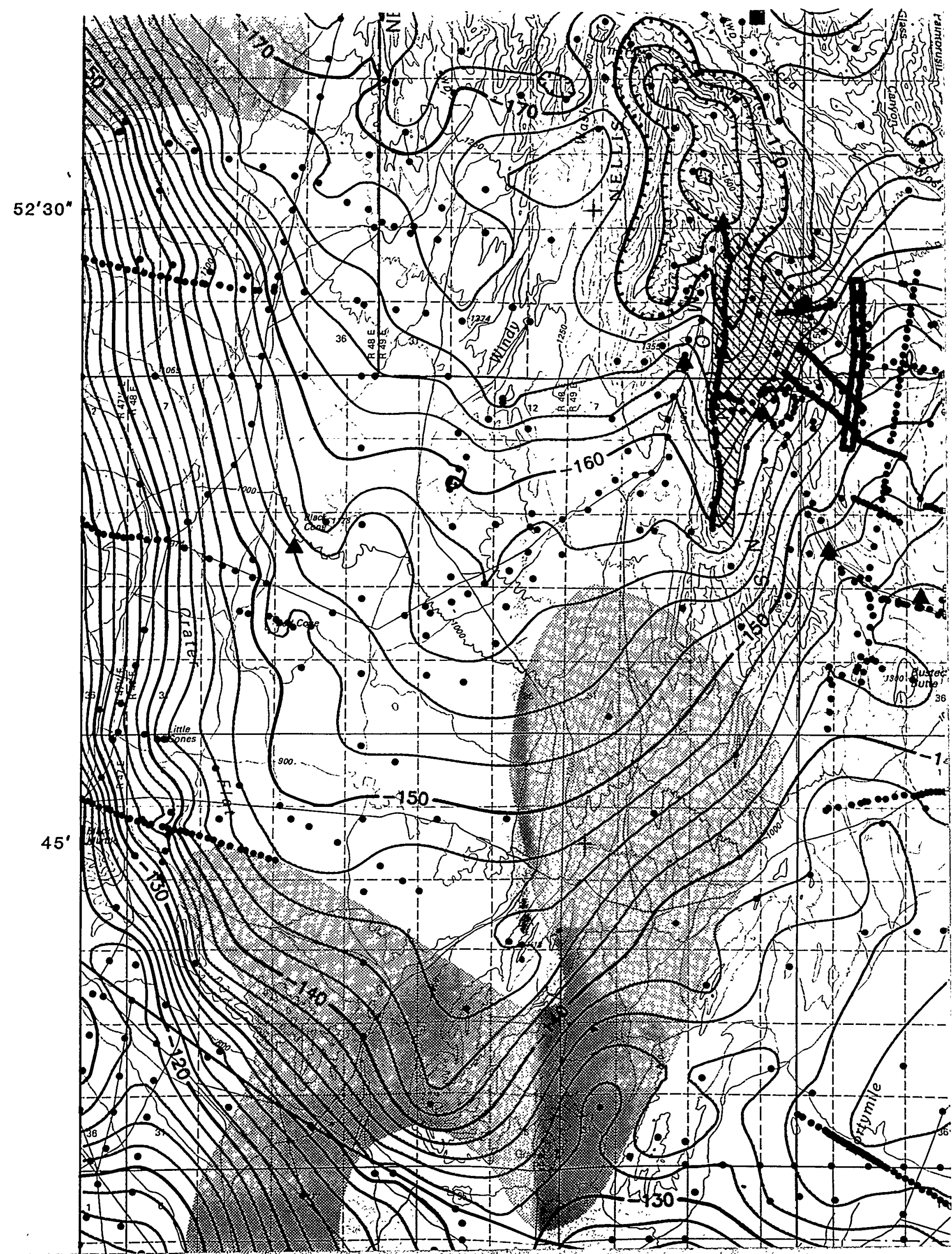


seismic exploration at the Nevada $s$ in the Geological Sciences: U.S. onal Paper 400-B, p. B156-B160.

W., 1987, Comparison of Timber $x$, Nevada, with Yellowstone: SpecDecker, R. W., ed., Hawaii sympoNork, Hilo, Hawaii, January 19-25, niversity of Hawaii at Hilo, p. 67 .

Ponce, D. A., and Oliver, H. W., bout 15,000 gravity stations in the aity: U.S. Geological Survey Open-

and seismic study of Yucca Flat, Inty, Nevada, in Mining Geophysics, Exploration Geopliysicists, v. 1, p.

f gravity data to geologic problems ickel, E.B., ed., Nevada Test Site: ca Memoir 110, p. 147-156.

of the Sturtevant Site, Nevada Test ey/Report USGS-474-59, 9. p.

ey of the UE15j site, Area 15, Nye ological Survey Report USGS-474-

rvey of Area 8, Nevada Test Site, i. Geological Survey Report USGS-

ion of gravity surveys in intermon$1 \mathrm{New}$ Mexico, in Site investigations Ain point Missile Systems, AWFLıpons Laboratory, Air Force Systems Force Base, New Mexico.

ts for gravity stations in the western zrees sheet, in Nevada: U.S. Geologport 76-57, 15 p.

s-Rainier Mesa and U12n.10 tunnel, in restigations in connection with the 1.10 tunnel, Nevada Test Site: U.S. USGS-474-288, p. 154-166.

estigations, in U.S. Geological Sursical investigations of Climax Stock Jeological Survey Open-File Report

., and Glover, D. A., 1984, Borehole lrill holes USWG-3, UE-25PPSI, and untain area, Nevada: U.S. Geological 84-0672, $18 \mathrm{p}$.

E., 1977, Principal facts for gravity a, Nye, Esmeralda, Lander, Eureka, s, Nevada: U.S. Geological Survey
Kane, M. F., Healey, D. L., Peterson, D. L., Kaufman, H. E., and Reidy, D., 1979, Bouguer gravity map of Nevada, Las Vegas sheet: Nevada Bureau of Mines and Geology Map 61, scale $1: 250,000$.

Kane, M. F., Webring, M. W., and Bhattacharyya, B. K., 1981, A preliminary analysis of gravity and aeromagnetic surveys of the Timber Mountain area, southern Nevada: U.S. Geological Survey Open-File Report 81-189, 40 p.

Miller, C. H., and Healey, D. L., 1986, Gravity interpretation of Frenchman Flat and vicinity, Nevada Test Site: U.S. Geological Survey Open-File Report 86-211, 44 p.

Miller, C. H., Healey, D. L., and Currey, F. E., 1974, Gravity map of the northern Nellis Air Force Bombing and Gunnery Range, Nevada: U.S. Geological Survey Geophysical Investigations Map GP-902, scale 1:125,000.

Morelli, C., ed., 1974, The International Gravity Standardization Net 1971: International Association of Geodesy Special Publication No. 4, $194 \mathrm{p}$.

National Geophysical Data Center, 1984, Defense Mapping Agency gravity file of the U.S.: available from National Geophysical Data Center, National Oceanic and Atmospheric Administration, Code E/Gcx2, 325 Brozdway, Boulder, CO 80303, 2 tapes.

Plouff, Donald, 1977, Preliminary documentation for a FORTRAN program to compute gravity terrain corrections based on topography digitized on a geographic grid: U.S. Geological Survey Open-File Report 77-535, 45 p.

Ponce, D. A., 1981, Preliminary gravity investigations of the Wahmonie Site, Nevada Test Site, Nye County, Nevada: U.S. Geological Survey Open-File Report 81-522,64 p., 1 plate.

Ponce, D. A., 1984, Gravity and magnetic evidence for a granitic intrusion near Wahmonie Site, Nevada Test Site, Nevada: Journal of Geophysical Research, v. 89, no. B11, p. 9,4019,413 .

Ponce, D. A. and Hanna, W. F., 1982, Preliminary appraisal of gravity and magnetic data at Syncline Ridge, western Yucca Flat, Nevada Test Site, Nye County, Nevada: U.S. Geological Survey Open-File Report 82-931, 19. p.

Reidy, D., Kane, M. F., Healey, D. L., Peterson, D. L., and Kaufman, H. E., 1978, Principal facts for a set of regional gravity data for the Las Vegas $1 \times 2$ degree sheet, Nevada: U.S. Geological Survey Open-File Report 78-1012, 36 p.

- - - 1979, Complete Bouguer gravity map of the Las Vegas 1 degree by 2 degrees sheet, Nevada: U.S. Geological Survey Open-File Report 79-531, scale 1:250,000.

Snyder, D. B., 1983, Interpretation of the Bouguer gravity map of Nevada, Caliente sheet: Nevada Bureau of Mines and Geology Report 37, 8 p.

Snyder, D. B., and Carr, W. J., 1982, Preliminary results of gravity investigations at Yucca Mountain and vicinity, southern Nye 


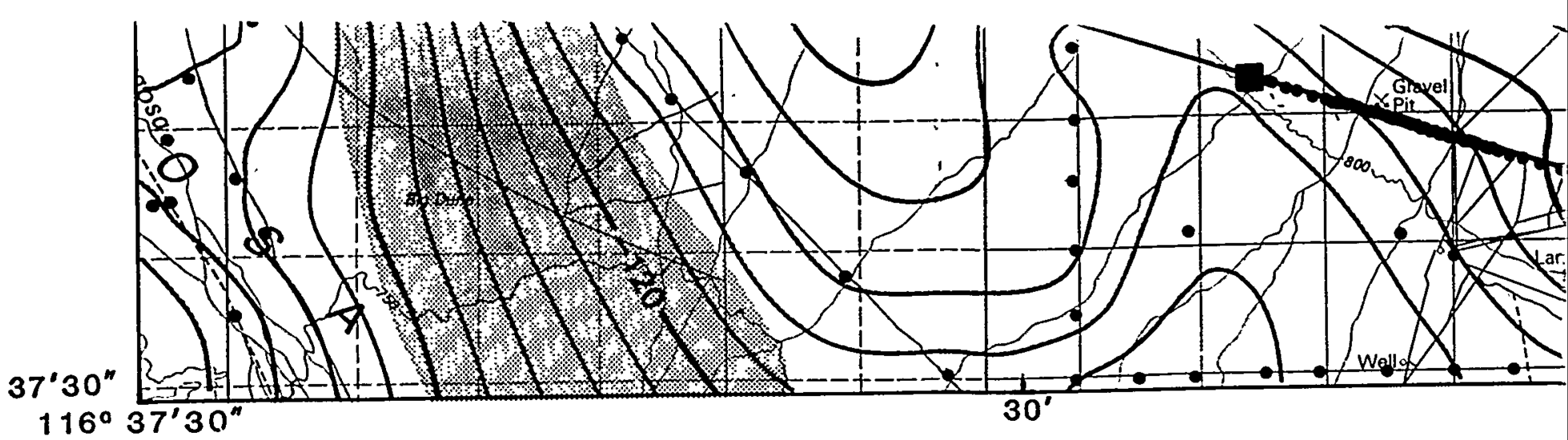

Base from U.S. Geological Survey 1:100,000 Indian Springs, 1976; Beatty, Pahranagat Range, 1978; Pahute Mese, 1979
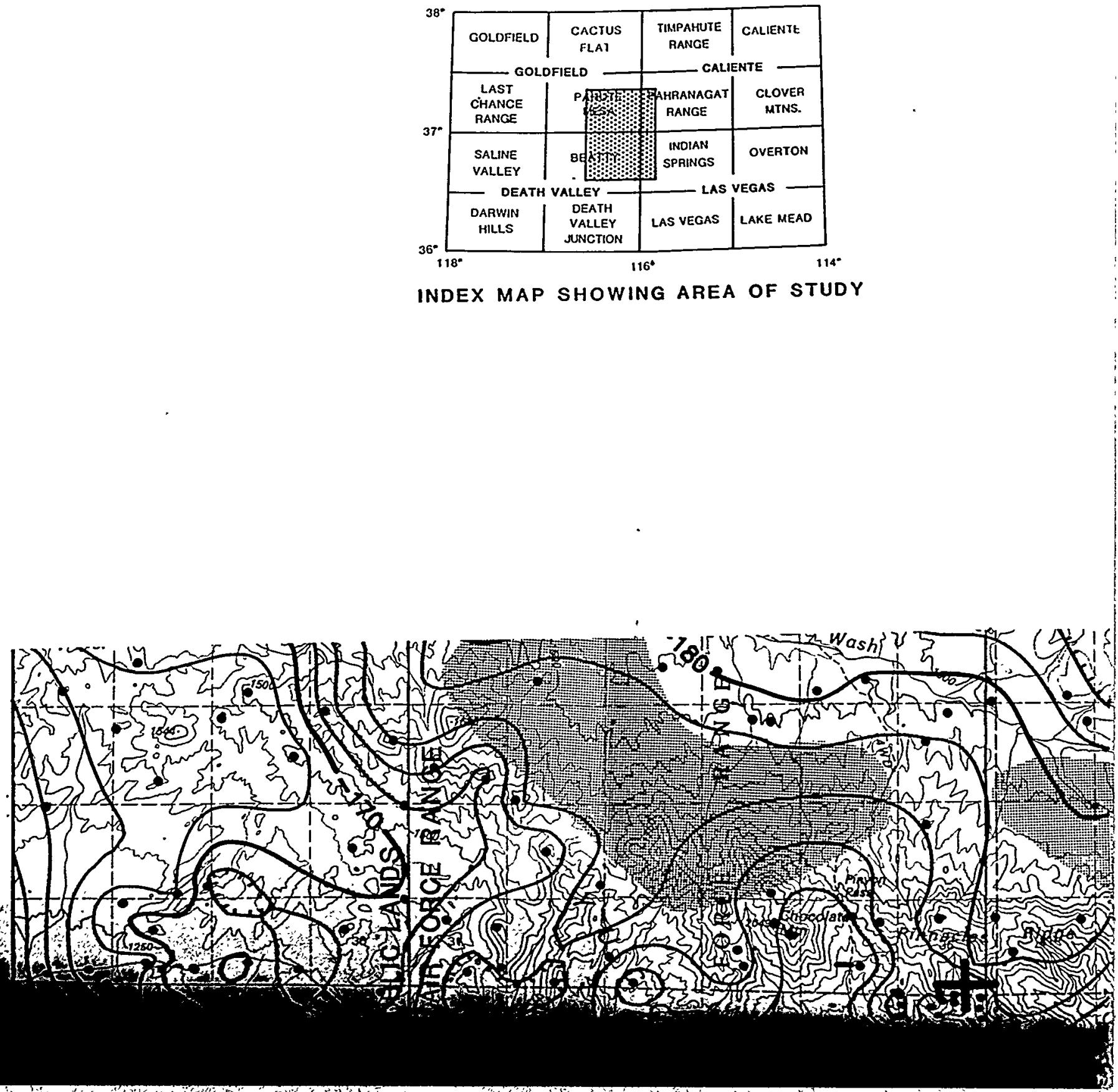


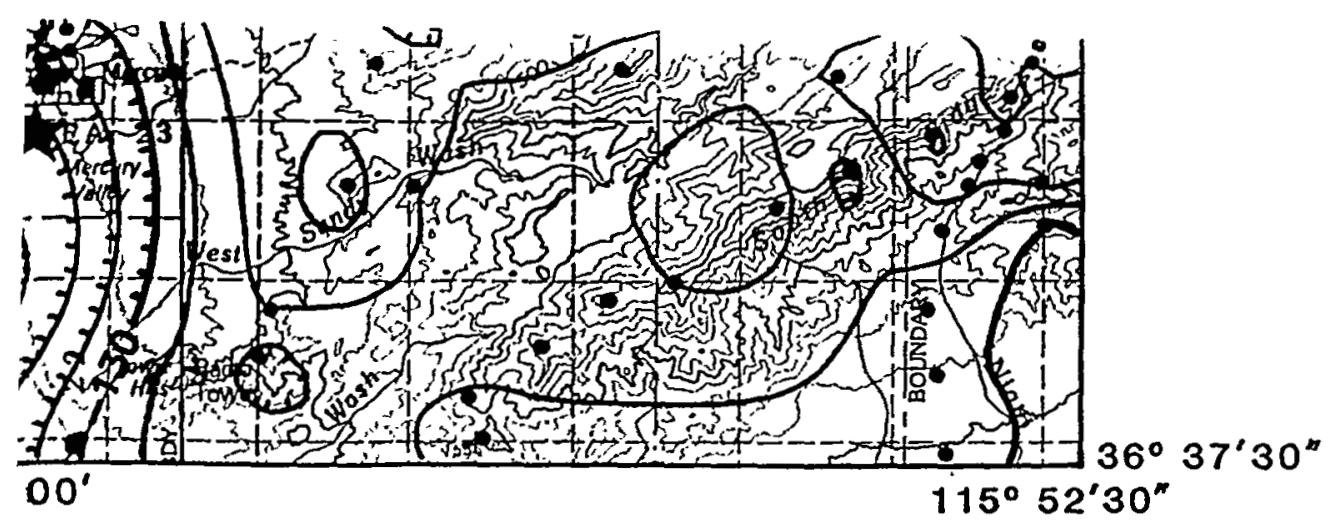

SOURCES OF GRAVITY DATA

stional Laboratory (A. H. Cogbill, written commun., 1986)

liysical Data Center (1984), and

I Survey:

'1976b)

ind Curry (1977)

ind others (1979)

D. L. (written commun., 1985)

and others (1982)

1981)

nd Hanna (1982)

nd others (1978)

and Oliver (1981)

and others (1981)

\section{DISCLAIMER}

Healey, D. L.s and Miller, C. H., 1962, Gravit Nevada Test Site and vicinity, Nye, Lincoln, $a$ ties, Nevada-interim report:|U.S. Geological : ements Investigations Report, TEI- 827, 36 p

- - - 1963, Gravity survey of the Gold Meado= Test Site, Nye County, Nevada, in Short Pape: Hydrology: U.S. Geological Survey Professio: p. 64-66.

_ _ - 1971, Gravity survey of the Amargos Nevada and California: U.S. Geological Surve 474-136, 29 p.

- - 1979, Interpretation of gravity data in $t 5$ tain area of the Nevada Test Site: U.S. Geol. port USGS-474-308, $47 \mathrm{p}$.

Healey, D. L., Snyder, D. B., Wahl, R. R., ar: 1981a, Bouguer gravity map of Nevada, $\mathrm{C} \varepsilon$ vada Bureau of Mines and Geology Map 70,

Healey, D. L., Wahl, R. R., Currey, F. E., a: E., 1979, Complete Bouguer gravity map o $\times 2^{\circ}$ sheet, Nevada and Utah: U.S. Geologic USGS-474-305, 75 p., scale 1:250,000.

Healey, D. L., Wahl, R. R., and Currey, F. F pal facts, accuracies, sources, and base static gravity stations in the Nevada part of the $G$ posa 2 degree sheets: U.S. Geological Surv 474-311, $12 \mathrm{p}$.

\begin{abstract}
port was prepared as an account of work sponsored by an agency of the United States overnment. Neither the United States Government nor any agency thereof, nor any of their employees, makes any warranty, express or implied, or assumes any legal liability or responsibility for the accuracy, completeness, or usefulness of any information, apparatus, product, or process disclosed, or represents that its use would not infringe privately owned rights. Reference herein to any specific commercial product, process, or service by trade name, trademark. manufacturer, or otherwise does not necessarily constitute or imply its endorsement, recommendation, or favoring by the United States Government or any agency thereof. The views and opinions of authors expressed herein do not necessarily state or reflect those of the United States Government or any agency thereof.
\end{abstract}

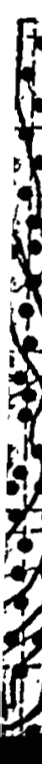

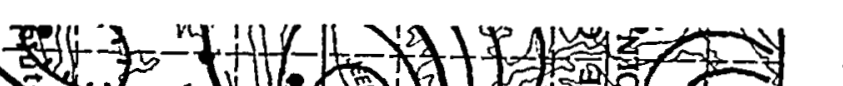

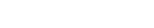
(1)
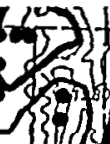

更

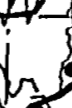
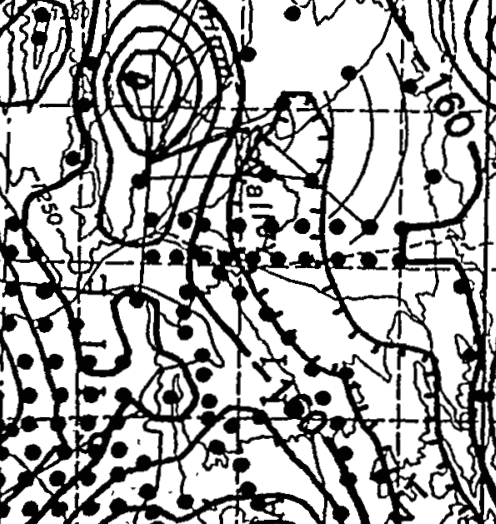

.

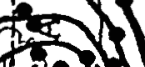

(3)

.

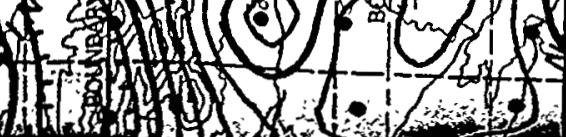

alle I una truuntian in ute sournwest quaarant o collected to help assess these areas as potential hi waste storage sites (Ponce and Hanna, 1982; Sny 1981; Ponce, 1981; Snyder and Carr, 1982)

Anderson, R. E., Ekren, E. B., and Healey, D. ble buried mineralized areas in Nye and Esme Nevada, in Geological Survel Research 1965: Survey Professional Paper 525-D, p. D144-D1

Carr, W. J., Bath, G. D., Healey, D. L., and Haz 1975, Geology of northern Frenchman Flat, Nd U.S. Geological Survey Report USGS-474-216, 
E, 1962, Gravity survey of the iNye, Lincoln, and Clark Counच.S. Geological Survey Trace El„TEI- 827, 36 p., 1 plate.

the Gold Meadows stock, Nevada n. in Short Papers in Geology and iurvey Professional Paper 475-B,

of the Amargosa Desert area of Ereological Survey Report USGS- .

Favity data in the Timber MounSite: U.S. Geological Survey Re-

Wahl, R. R., and Currey, F. E., s of Nevada, Caliente sheet: Ne'eology Map 70, scale 1:250,000.

urrey, F. E., and Stephens, W. gravity map of the Caliente $1^{\circ}$ : U.S. Geological Survey Report $: 250,000$.

d Currey, F. E., 1981b, Princiand base station descriptions for a part of the Goldfield and Mari'eological Survey Report USGS-
- $\ldots, 1984$, Interpretation of gravity data in a complex volcanotectonic setting, southwestern Nevada: Journal of Geophysical Research, v. 89, no. B11, p. 10,193-10,206.

Snyder, D. B., and Oliver, H. W., 1981, Preliminary results of gravity investigations of the Calico Hills, Nevada Test Site, Nye County, Nevada: U.S. Geological Survey Open-File Report $81-101,42 \mathrm{p}$.

Snyder, D. B., Tang, R. W., Oliver, H. W., and Morin, R. L., 1981, Principal facts, accuracies, sources, base station descriptions, and plots for 2,255 new and revised gravity stations in the western half of the Caliente $1 \times 2$ degree quadrangle, Nevada and Utah: available from National Technical Information Service, U.S. Department of Commerce, Springfield, VA 22152, PB81-1780, $101 \mathrm{p}$.

Swick, C. H., 1942, Pendulum gravity measurements and isostatic reductions: U.S. Coast and Geodetic Survey Special Publication 232, $82 \mathrm{p}$.

U.S. Department of Energy, 1984, Draft Environmental Assessment-Yucca Mountain Site, Nevada Research and Development Area, Nevada: U.S. Department of Energy Report DOE/ RW-0012.

U.S. Geological Survey, 1968, Transcontinental geophysical survey (35-39W), Bouguer gravity map from $112 \mathrm{~W}$ longitude to the Coast of California: U.S. Geological Survey Miscellaneous Investigations Map I-532-8.

Wahl, R. R., 1969, An analysis of gravity data in Area 12, Nevada Test Site: U.S. Geological Survey Open-File Report 69-1289, 23 p., 3 plates.

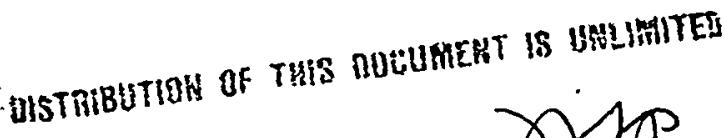

\section{REFERENCES}

This map is preliminary and has not been reviewed for conformity with U.S. Geological Survey editorial standards and stratigraphic nomenclature. Any use of trade names is for descriptive purposes only and does not imply endorsement by the USGS.

nd Healey, D. L., 1965, PossiWye and Esmeralda Clounties, Research 1965:, UW'S Géological.

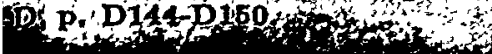

Healey, D. L., Wahl, R. R., and Oliver, H. W., 1980, Bouguer gravity map of Nevada, Death Valley sheet: Nevada Bureau of Mines and Geology Map 69, scale, 1;260,000. 